\title{
Outsourcing Practices in State-Owned Enterprises: Evidence From Indonesia
}

\author{
Tri Hastuti ${ }^{1}$, Yos Johan Utama ${ }^{2}$, M Mashari ${ }^{1} \&$ H Hersugondo ${ }^{2}$ \\ ${ }^{1} 17$ Agustus 1945 University, Semarang, Indonesia \\ ${ }^{2}$ Diponegoro University, Semarang, Indonesia \\ Corespondence: H Hersugondo, Diponegoro University, Semarang, Indonesia. E-mail: \\ Hersugondo@lecturer.undip.ac.id
}

Received: February 19, 2020

Accepted: April 3, 2020

Online Published: June 18, 2020

doi:10.5430/rwe.v11n3p224

URL: https://doi.org/10.5430/rwe.v11n3p224

\begin{abstract}
This study is subject to find the factors that cause the inability of the Government in determining the type of work in the job chartering (outsourcing) by the Business Sector Association to create a flow of work activities. The authority of the Business Sector Association in making the flow of activities that determine itself the type of core work (core business) and supporting work (non-core business) when violations occur so it needs to be limited by the Government through agencies that are experts in their fields. This research method used a socio legal approach since it involved a reciprocal relationship between law and related social institutions. This research is considered as a descriptive study that described the object studied in several companies of State-Owned Enterprises (SOEs) that applied outsourcing practices in the city of Semarang. The results of the study found that the practice of outsourcing in the city of Semarang has identified several violations namely the existence of the Business Sector Association in determining the type of core work (core business) to be a supporting work (non-core business) so that it violated Article 65 paragraph (3) of Law Number 13 Year 2003 concerning The Employment. The inability of the Government in outsourcing practices is dominated by corporate strategy factors through the Business Sector Association in making the flow of activities that should use the outsourcing system for types of supporting work (non core business) to become core work (core business) by using outsourcing and supporting systems (non core business) by the Business Sector Association in creating the flow of activities to determine for themselves the type of core work (core business) so that there would be an efficiency and optimization of the core business activities of a company.
\end{abstract}

Keywords: government inability, determination of the type of work, a job chartering (outsourcing)

\section{Introduction}

The National development for all Indonesian people still faces crucial issues regarding the surrender of part of the work to other companies, whether through employment contracting or the provision of services for workers / labors known as outsourcing. The implementation of outsourcing since 2000 has become popular, in addition to being seen as more efficient in a management system, outsourcing can be a solution to improve the efficiency of production costs (cost of production) (Adrian Sutedi, 2011), especially in order to reduce labor costs (labor costs) (Andi Fariana, 2012).

The government is actually reduceing employers (Bales, 2014). Obligations in providing legal protection for workers or laborers. Policies in the field of employment (employment policy) both at the local and national levels are considered not to lead to efforts to protect (social protection) for workers or labors. Employment policy actually leads to efforts to make workers or labors as part of market mechanisms and components of production that have exploitative gaps for investors (Umi Kholifah, 2010).

The use of outsourced workers is not only done by companies of State-Owned Enterprises (SOEs) and also by Government agencies (Indonesian Trade Union Confederation and Legal Aid Services Jakarta, "Eliminate Outsourcing in State Owned Enterprises." Pers Conference on August 22 $2^{\text {nd }}, 2013$ ). Outsourcing in the business world is seen as a method to improve production efficiency, provide flexibility for working conditions, creating expertise and grow companies that are experts in their fields and cost efficiency as well. 
Based on the provisions in Article 64 of Law Number 13 Year 2003 concerning Manpower, it is stated that the company can submit some of the work implementation to other companies through work contracting agreements or the provision of services of workers / labors in writing. In the implementation of the Government through the Regulation of the Minister of Manpower and Transmigration of the Republic of Indonesia Number 19 of 2012 about Conditions of Submission of Partial Work Implementation to Other Companies. The provisions in Article 3 mentioned that: (1) The employing company may submit a portion of the execution of work to the receiving outsource company; and (2) Work that can be submitted to the receiving outsouce company.

The Outsourcing arrangements must be set forth in a written agreement and must be registered with the Department of Manpower, as stipulated in the Decree of the Minister of Manpower and Transmigration of the Republic of Indonesia Number 101 of 2004. Thorough and comprehensive arrangements, which include human resource development, productivity improvement, and competitiveness of Indonesian workers / labors, employment expands opportunities efforts, employment / labor placement services and fostering work relationships aimed at improving the welfare of workers / labors in particular and the welfare of society in general (H. Salim HS, 2008).

Problems faced by outsourcing companies in conducting their business, after the issuance of regulations by the Ministry of Manpower and Transmigration No. 19 of 2012. According to Iftida Yasar (Iftida Yasar, 2014) there are five problems faced by outsourcing business providers, this problem must be sought jointly by the government and associations. These problems include: First, the high unemployment rate in the community due to unbalanced labor supply and demand. Second, labor productivity is still low. This is due to the low level of education and competence possessed by the workforce offered to the company. Third, the determination of the minimum annual wage has not been linked to the productivity and minimum competencies that the workforce must possess. Fourth, there are many politicians or parties who take advantage of workers' demands and acted on their behalf to achieve a certain position. Fifth, the legal certainty and guarantee on the continuity of doing business for the company is still low.

This study aimed to analyze the inability of the Government in determining the type of work in the job chartering by the Business Sector Association to create work flow activities that lead to irregularities in determining the type of core work (core business) to support (non core business) so that companies no longer have the right to determine their own path work activities that guarantee freedom of choice and equality of opportunity for outsourcers.

\section{Method}

This study used a non-doctrinal research with a sociolegal approach (socio-legal approach) since the research involved a reciprocal relationship between law and related social institutions (Bhattacherjee, 2012). Socio-legal approach to the description of social and legal realities, and to try to understand and explain the logic of logical connection between the two (Satjipto Rahardjo, 1980). The socio-legal study in the realm of reality is expected to have the understanding whether the positive laws that exist and the laws that are created from patterns of relationship between subjects in this society can make a balance of employment relationships for outsourcing workers, outsourcing service providers, and companies as it is possible that there would be conflicts of opinion among users of labor service users.

The object that being studied is the practice of outsourcing and the legal system that surrounds it in the city of Semarang. This research carefully described the characteristics of the facts (individuals, groups, or circumstances), and to determine the phenomena that occur in this context the research to be investigated is called descriptive research (Rianto Adi, 2004). Sources of Research Data, the data sources needed in this study are primary and secondary data. Primary data is obtained directly from the object, namely Informants, and Respondents, while secondary data are sourced from written documents in the form of: outsourcing contract agreements, scientific journals, documents, books, dissertations, magazines, newspapers, archives and laws.

The data analysis in this study has followed the qualitative research model of Mattew B. Miles and A. Michael Haberman consisting of data collection activities, data reduction, data display, and drawing conclusions / verification (Conclusion Drawing / Verification) (Sugiyono, 2010). Data Validation was implemented in order to keep the validity and objectivity of the data secured therefore triangulation inspection techniques were used. This research used source triangulation and method techniques. Triangulation of sources and techniques is done by verifying the source of data and techniques from one another, both obtained through interviews, observation, documentation studies.

\section{Results and Discussion}

1. The Concept of Determining the Type of Work in the Core and Support Job Chartering by Business Sector Associations 
Rejection of the outsourcing system occurred quite often and almost happened throughout Indonesia. This demand does not only occur in private companies, but also in state-owned companies (SOE). Like the case of labor outsourcing disputes that occurred at PT. Telkom, which the news was published in a number of mass media and national newspapers (Rastra Sewakitiara, 2015). According to the workers, the management of PT. Telkom refused to appoint hundreds of workers outsourcing security and cleaning services to become permanent employees (Sabda Pranawa Djati, 2015).

Worker outsourcing disputes in labor-intensive industries in multinational cigarette companies. Labors from the Worker Service Provider Company (PPJP) who placed in the cigarette company had identified that there was violations of labor law in their outsourcing work agreement (Ady, 2015). According to Ady as a worker, the company delegates its main production activities (not supporting activities) to third parties by outsourcing.

The work agreements on job chartering (outsourcing) in labor law in Indonesia are based on Article 64 - 65 of Law Number 13 Year 2003 concerning Manpower. The agreement must be made in writing, taking into account several provisions in general contractual law. In Law Number 13 Year 2003 concerning Manpower has limited jobs that can be submitted to other companies through chartering or outsourcing. The provision in Article 65 paragraph (2) stated that work that can be submitted to other companies must fulfill the following requirements: (a) it is carried out separately from the main activity; (b) done by direct order; (c) constitutes overall company support activities; and (d) does not directly inhibit the production process.

According to Sri Nurhaningsih (Sri Nurhaningsih, 2017) as Director of Job Requirements, Welfare and Discrimination Analysis of Minister of Manpower and Transmigration decree (Kepmanakertrans) said that many parties were fooled so that interpreting outsourcing could only be done for 5 (five) types of work. In fact, referring to Article 64 of Law Number 13 Year 2003 concerning Manpower, all types of work that fall into the category of supporting activities may be outsourced. Submission of partial work to other companies or known as outsourcing, according to Nurhaningsih, it can be done through job chartering.

Based on Minister of Manpower and Transmigration Regulation Number 19 of 2012 concerning Terms of Submission of Partial Work Implementation to Other Companies, there are restrictions on 5 (five) types of work for outsourcing using Worker Service Provider Company (PPJP) mechanism. According to Nurhaningsih said that in the mining and petroleum sector, positions that could be outsourced through Worker Service Provider Company (PPJP) were broader. According to her, the various types of positions contained in several Regulations of Energy, Natural Resources and Mineral (ESDM) Minister.

According to Nurhaningsih (Sri Nurhaningsih, 2017) that the Department of Manpower in several regions lacked understanding of the matter, so the employer companies which wished to have jobs chartering in 5 (five) types of work that were restricted in Worker Service Provider Company (PPJP) were having difficulties or not given an operational permit. Several types of work are in gray areas, so it is considered difficult to find whether they are in the type of core or supporting activities. Even though the support is categorized whether it can be outsourced with the Worker Service Provider Company (PPJP) mechanism. For example, secretaries and couriers of the two types of work cannot be outsourced using the Worker Service Provider Company (PPJP) mechanism but can be done by contracting jobs.

The Government issued Law No. 13 of 2003 concerning Manpower stating that the needs of companies to run production could use labor supplies by outsourcing companies. The main thing regulated in the Law is the binding of labor, the provision of wages, the determination of suppliers of outsourcing workers and also the type of work that can be outsourced is supporting work only.

The Government through the Minister of Manpower and Transmigration issued the regulation (Permenakertrans) Number 19 of 2012 on job chartering and Employment Services (outsourcing) to clarify the previous Law. Examples of the types of work that can be delegated to the workforce are jobs that are as supportive jobs including: cleaning, security, transportation, catering services as well as mining and petroleum supporting work.

The concept of determining the type of work by business sector associations in making the flow of activities there has been a deviation in the determination of the type of core work (core business) to be supporting work (non-core business). The Government, through Technical Agencies that are experts in their fields, limits the types of core work and non-core businesses to provide guidance and supervision so that the authority of the Business Sector Association in making work activities flow limits the types of main job (core business) to become a support work (non core business). 
2. Regulation on the Determination of the Type of Work in the Work Chartering for Partial Implementation of Work to Other Companies

Protection of workers is a state promise set forth in the Constitution Article 28D paragraph (2) of the 1945 Constitution which mentioned that "Everyone has the right to work and to receive fair and appropriate compensation and treatment in employment relations". The provisions of outsourcing in Law Number 13 Year 2003 on Manpower and regulations under it are still far from the context of justice as mandated by the constitution. Regulators must be guided by the principle of establishing good laws and regulations as referred to in Article 5 of Law Number 12 of 2011 concerning Formation of Regulations.

Regulation on Law Number 13 of 2003 concerning Manpower as a legal basis for the implementation of outsourcing in Indonesia is divided into two parts, namely: the employment of labors and the provision of workers / labors services. Review on job contracting of the implementation of partial work to other companies on supporting activities or activities that are not directly related to the production process are activities that are outside the main business (the core business) of a company.

One of the contents of Law Number 13 of 2003 concerning Manpower is related to outsourcing regulated in Articles 64, 65 and 66. Based on Law Number 13 of 2003 concerning Manpower has justified the submission of implementation on partial work to the company another or company that providing labor / labor services through contracting / providing workers / labor services (Abdul Khakim,2007)

The analysis on Law Number 13 Year 2003 regarding Manpower is not so in the study since it gave a less attention to the principle of precision or accuracy. In general, good regulations must be based on the philosophy of a nation or must be based on values that live in society, so that these regulations are expected to be accepted and effective in the community as well as provide protection and have legal certainty.

Based on the principle of precision or accuracy, it can be seen in the general provisions that usually contain the notions of the material to be further arranged. In this provision, it does not explain what is meant by the partial work submission, chartering agreements and the provision of services for workers and other companies. The provisions of the explanation content is also "quite clear" whereas according to the author there are some provisions that require further explanation. Formation of Law Number 13 of 2003 concerning Manpower specifically related to outsourcing is contrary to the Law Number 28 of 1999 concerning general principles of Good Governance.

Based on this matter, several problems can be explained juridically for the outsourcing arrangements, including:

a. By Conceptual side, vertically,outsourcing arrangements are considered contrary to the Preamble and Body of the 1945 Constitution. Horizontally, outsourcing arrangements are considered to reduce the implementation of other legislation in the field of labor, especially in relation to the implementation of labor social security and the effectiveness of freedom of association for workers. Internally, outsourcing arrangements are not in line with the regulation of Indonesian Industrial Relations based on the values of the Pancasila (Five Basic Principles) and the 1945 State Constitution (Romi, 2015).

b. The formulation of the provisions in Article 64 which combined the submission of partial works through contractual agreements and the provision of services for workers who later became known as outsourcing. In the legal context, according to the author, there are two different things. As we have known for chartering agreement through Book III Chapter 7A article 1601 of the Civil Code.

Based on the knowledge of job chartering, it can be seen from the legal construction that there are job owners who chartered the jobs to contractor. Job contractor is obliged to complete the work he received from the job owner, so the contractor recruits workers who will carry out the work, so that in the relationship between the contractor and the worker there is a work relationship.

Agreement on the provision of workers' services which in fact relatively new in our law, we can find out the legal construction, namely there are companies that need workers who will complete the work available in their company, but those who recruit workers are handed over to other companies or by Law Number 13 of 2003 concerning Manpower is referred to as a service provider company. Service provider companies only placed workers in companies that need them (Candra Suwondo, 2004).

The concept of industrial relations in an outsourcing system is vague or biased. This can be seen from the definition of outsourcing and is connected with the provisions of article 1 paragraph (15) of Law Number 13 of 2003 concerning Manpower. In general, the meaning of outsourcing is the delegation of operations and daily 
management of a business process to an outsider (outsourcing service provider or using human resources from outside the company (Adrian Sutedi, 2011). Workers are employed by service providers at user companies. Not working at their companies.

Based on the provisions of Article 1 number 15 of Law Number 13 of 2003 concerning Manpower which mentioned that: "Employment relation is the relation between employer and workers / labors based on work agreements, which have elements of work, wages, and orders". Article 65 paragraph (6): that the employment relationship in the performance of work as referred to in paragraph (1) shall be regulated in a written work agreement between the other company and the workers /laborers who being employed.

The Government issued Minister of Manpower and Transmigration Regulation (Permenakertrans) Number 19 of 2012 and Circular letter of the Minister of Manpower and Transmigration of the Republic of Indonesia Number SE.04 / Men / VIII / 2013 concerning Guidelines for Implementing Regulation of the Minister of Manpower and Transmigration of the Republic of Indonesia Number 19 of 2012 concerning Terms of Submission of Partial Work Implementation to Other Companies. This Circular letter can reinforce the implementation of outsourcing, but the fundamental issues such as the Transfer of Undertaking Protection of Employment (TUPE) or "Continuation of Work Guarantee" have not yet been explicitly regulated.

3. The Inability of the Government to Determine the Type of Work in Jobs Chartering

The rejection of the outsourcing system is getting tougher, marked by the union's actions to continue to express strong protest against outsourcing. Protest of Non-Governmental Organizations Alliance of Indonesian Electric Meter Readers (AP2ML) following action of the previous Trade Union struggles, by submitting a material test to the Constitutional Court (MK) on Article 59 (about PKWT/ Unspecified Time Work Agreement) and Article 64 (regarding outsourcing) up to Article 66 of the Law Law Number 13 Year2003 on Employment. Analysis of the articles is considered to be contrary to the 1945 State Constitution Article 27 paragraph (2), Article 28 D paragraph (2), and Article 33 paragraph (1) (Minutes of Constitutional Court Session Number 27/PUU/3011, May 2011).

The Government's own response in the trial at the Constitutional Court showed a stance in favor of outsourcing. According to the government, the employment relationship is based on PKWT (Unspecified Time Work Agreement) and the submission of partial work to other companies as stipulated in Article 59 and Article 64 of Law Number 13 Year 2003 concerning Manpower. A fair and proper treatment for all citizens in work relations in order to get a reward commensurate with the work carried out (Minutes of Constitutional Court Session Number 27/PUU-IX/2011, 2011). The government believes that outsourcing is a work system that is not as bad as what workers think. Conversely, the existence of outsourcing will help in channeling those who have not yet worked.

The petition for the material test, the Constitutional Court then issued Decision Number 27 / PUU-IX / 2011 concerning outsourcing which, in its main consideration, the Constitutional Court was of the opinion that Article 65 paragraph (7) and Article 66 paragraph (2) letter b of Law Number 13 Year 2003 on Manpower is conditionally contradictory to the 1945 Constitution (conditionally unconstitutional) (Indonesia, Constitutional Court, Verdict Number 27/PUU-IX/2011). The Constitutional Court also believed that the reason that outsourcing cannot be removed is the sociological condition of the Indonesian people. The birth of the Constitutional Court's decision is expected to reduce the outsourcing problems in Indonesia. Decision of the Constitutional Court Number 27 / PUU-IX / 2011 directly makes Law Number 13 of 2003 concerning Labor underwent significant legal changes.

The government conducted a search and research on the Constitutional Court Decision Number 27 / PUU-IX / 2011 to provide an explanation of the definition of outsourcing. Equitable outsourcing according to the Constitutional Court is outsourcing carried out by guaranteeing (Minutes of Constitutional Court Number 27/PUU-IX/2011, Januari 17 $7^{\text {th }}$ 2012): (1) Continuation of employment of workers, the Constitutional Court requires that employment agreements between workers and outsourcing companies on the basis of an Unspecified Time Work Agreement (PKWTT) the principle of transfer of protection for workers should be applied the Transfer of Undertaking Protection of Employment (TUPE); (2) Continuing the existing work agreement, the existing work agreement must be continued without changing the provisions in the work agreement; (3) Calculation of years of service, the years that have been passed by the outsourcing workers are still considered to exist and are taken into account; and (4) Equality between workers, the employer company must arrange for outsourcing workers who do the exact same work as workers at the employer to receive fair benefits and welfare without any discrimination.

The inability of the Government in determining the type of work in the chartering of work by the Business Sector Association is based on the provisions of Article 3 paragraph (2) letter (c) Minister of Manpower and Transmigration Number 19 of 2012 mentioned that business sector associations as institutions that are authorized to determine the 
flow of activities of the company's work. The government considered that it's necessary to give authority to business sector associations to determine the flow of business activities of the company, but in reality there has been a distortion in determining the type of core work (core business) to become a support work (non-core business).

According to Dwi Maryoso (Dwi Maryoso, 2019) that the Government through related technical agencies whoare experts in their fields by ratifying the flow of work activities to determine the type of core business and non-core business work so as to provide legal protection to the rights and obligations of the company that receiving jobs, including the interests of workers and employers get protection for the certainty of their rights as well. The government considered that it's necessary to authorize business sector associations to determine the flow of business activities of the company. The fact is that business sector associations when making the work flow have occurred violations in determining the type of core work to support the process of carrying out the company's work. The inability of the Government in determining the type of work in the chartering of jobs by the Business Sector Association in making the flow of work activities because this problem must be handled by people who are experts in their fields. The Government through relevant technical agencies whose experts in their fields must be able to overcome the problem of determining the type of work in the job chartering (outsourcing) by the Trade Organizations. The determination of the type of job chartering should be further regulated in Law Number 13 of 2003 concerning Manpower so that the rights and obligations of the company which accepting job, including the interests of workers can be more protected and employers would get protection for the certainty of their rights.

\section{Conclusion}

The inability of the Government in determining the type of work in the jobs chartering by the Business Sector Association to create work flow activities because it does not yet have any experts related to work flow activities making. Job hiring is the full authority of the Business Sector Association, where there has been a violation in determining the type of core business to become a non-core business. The authority of the Business Sector Association in making the flow of work activities to prevent violations from occurring needs to be fostered and supervised by the Government through relevant Technical Agencies that are experts in their fields so that companies no longer have the right to determine their own work flow.

The aim is to provide guidance and supervision by the Government through relevant technical agencies whose experts in their fields are expected to protect the rights and obligations of the company which receiving works, including the interests of workers and employers to get protection of the certainty of their rights.

\section{References}

Abdul Khakim. (2007). Hukum Ketenagakerjaan Indonesia. Citra Aditya Bakti, Bandung.

Adrian Sutedi. (2011). Hukum Perburuhan. Sinar Grafika, Jakarta.

Ady. Praktik Outsourcing Perusahaan Rokok Dilaporkan ke ILO. Retrieved 30 Mei 2015, from http://hukumonline.com/berita/baca/lt51a337c4312cc/praktik-outsourcing-perusahaan-rokok-dilaporkan-ke-ILO

Andi Fariana. (2012). Aspek Legal Sumber Daya Manusia Menurut Hukum Ketenagakerjaan. Mitra Wacana Meida, Jakarta.

Bales Richard. (2014). A Comparative Analysis of Labor Outsourcing. Arizona Journal of International \& Comparative Law, 31(3).

Bhattacherjee, A. (2012). Social Science Research: Principles, Methods, and Practices (2nd ed.). Creative Commons Attribution-NonCommercial-ShareAlike 3.0 Unported License.

Candra Suwondo. (2004). Outsorcing, Implementasi di Indonesia. Gramedia, Jakarta.

Dwi Maryoso. Selaku Mediator Hubungan Industrial di Dinas Tenaga Kerja dan Transmigrasi Provinsi Jawa Tengah, 3 Januari 2.

H. Salim HS. (2008). Perancangan Kontrak dan Memorandum of Understanding. Sinar Grafika, Jakarta.

Iftida Yasar. Wakil Sekretaris Umum Dewan Pimpinan Nasional Asosiasi Pengusaha Indonesia (Apindo). kepada Bisnis.com, 1 Juli 2014.

Indonesia, Mahkamah Konstitusi, Putusan No. 27/PUU-IX/2011.

Indonesia, Risalah Sidang Mahkamah Konstitusi Nomor 27/PUU-IX/2011 perihal Pengujian Undang-Undang Repubik Indonesia Nomor 13 Tahun 2003 tentang Ketenagakerjaan terhadap Undang-Undang Dasar Negara Republik Indonesia Tahun 1945. Acara Pemeriksaan Perbaikan Permohonan (II), Jakarta, Mei 2011. 
Indonesia, Risalah Sidang Mahkamah Konstitusi Nomor 27/PUU-IX/2011 perihal Pengujian Undang-Undang Repubik Indonesia Nomor 13 Tahun 2003 tentang Ketenagakerjaan terhadap Undang-Undang Dasar Negara Republik Indonesia Tahun 1945. Acara Mendengarkan Keterangan Pemerintah, DPR, dan Saksi/Ahli dari Pemohon dan Pemerintah (III), Jakarta, 6 Juli 2011.

Indonesia, Risalah Sidang Mahkamah Konstitusi Nomor 27/PUU-IX/2011 perihal Pengujian Undang-Undang Republik Indonesia Nomor 13 Tahun 2003 tentang Ketenagakerjaan terhadap Undang-Undang Dasar Negara Republik Indonesia Tahun 1945. Acara Pengucapan Putusan, 17 Januari 2012.

Konfederasi Serikat Pekerja Indonesia (KSPI) dan LBH Jakarta. Hapuskan Outsourcing di BUMN, Siaran Pers 22 Agustus 2013.

Rastra Sewakitiara. Putusan PHI Jakarta Menjadi Penentu Kehidupan Pekerja BUMN. Retrieved 9 April 2015, from http://indonesiana.tempo.com/read/39391/2015/04/09/sewakitiara/putusan-phi-jakarta-menjadi-penentu-kehidup an-pekerja-bumn

Rianto Adi. (2004). Metode Penelitian Sosial dan Hukum. Granit.

Romi. (2015). Asas Kepastian Hukum Dalam Pengaturan Perjanjian Kerja Waktu Tertentu Menurut Undang-Undang Nomor 13 Tahun 2003 Tentang Ketenagakerjaan. PPs Universitas Pajajaran, Bandung.

Sabda Pranawa Djati. Mark Up atau Eksploitasi Buruh di PT. Telkom. Retrieved 9 April 2015, from http://www.kompasiana.com/sabdapranawadjati/mark-up-atau-eksploitasi-buruh-dipttelkom_552b3de66ea834ff $25552 \mathrm{~d} 54$

Satjipto Rahardjo. (1980). Hukum dan Masyarakat. Alumni, Bandung.

Sri Nurhaningsih. Selaku Direktur Persyaratan Kerja, Kesejahteraan dan Analisis Diskriminasi Kemnakertrans. tanggal 24 Maret 217.

Sugiyono. (2010). Metode Pendekatan Pendidikan Penelitian Kualitatif Kuantitatif dan R\&D. Penerbit Alfabeta, Bandung.

Umi Kholifah. (2010). Perlindungan Hukum Bagi Tenaga Kerja Outsourcing Berdasarkan Undang-Undang No.13 Tahun 2003 Tentang Ketenagakerjaan, dalam Laksanto Utomo, 2014, Permasalahan Outsourcing Dalam Sistem Ketenagakerjaan di Indonesia. Jurnal Lex Publica, I(1), November 2014. 